The latest Unesco activity of the kind has been a recent training course held in Morocco. Organized by the Middle-East Science Co-operation Office of Unesco (Cairo), acting through its enthusiastic and energetic director, Mr. Jan Smid, the course owed its origin to an official invitation extended by the Moroccan Government during the general conference of Unesco at Cairo in November 1960. Held in Casablanca during November 23-December 20, 1961, this course was the first Unesco activity of the kind to be staged in the region.

The twenty persons who attended it came from Kuwait, Lebanon, Libya, Egypt, Sudan, Syria, Tunisia, Turkey and Morocco. Half had English as their second language and half French. The director of the course was Dr. J. N. Carruthers of the British National Institute of Oceanography, and the tutor in marine biology was Dr. Raoul Serène, the former director of the Nhatrang Institute. The Moroccan Government displayed great interest in the course, which was publicly opened before a large concourse by the acting Minister of Education accompanied by other officials. Hospitality was on a generous scale, and the requisite transport facilities were provided. Great help was received from the resident French members of the Institute's staff, and the director, Monsieur F. Varlet, made the two small vessels belonging to the Station available for the purposes of the course whenever desired. The excellent aquarium was a great boon for instructional purposes, and the controlling authority, the Marine Marchande, arranged excellent visits to the sardine port of Safi and to the oyster lagoons at Oualidia. The Ministry of Education provided bus transport. A day was spent examining beach fauna and flora under the guidance of Mlle. Gantes, of Rabat University.

The tuition given ranged broadly over all the aspects of physical oceanography and marine biology likely to be most useful to students of degree standard, but every effort was made throughout to teach things which the participants would, in turn, be able to teach in their own countries. To this end, demonstrations were made at sea of simple instruments of little cost and no difficulty with which the returning students would easily bo able to furnish themselves in order to start some elementary oceanographical teaching of their own nationals. The aim of the course was not to convey massive instruction but to arouse interest enough in things which can be done with very modest resources, to give grounds for the hope that some attention would be paid to the marine sciences in the countries from which the students came. This seems to be by far the best target for such Unesco activities, and, to further tho aim in question, a comprehensive suite of simple instruments and a wide selection of suitable hand-books and charts were taken out from Britain. In addition, a number of suitable instruetional films of British and American origin were exhibited during the course.

As expected, the participants differed widely among themselves in respect both of academic background and personal interest, and it became clear that their chances of arousing interest in oceanographical matters in their own countries would differ also.

Throughout the course the instruction had to be kept flexible both in physical oceanography and marine biology. As discovered also on a previous occasion, it would be unwise and unprofitable to attempt to teach such a course in keeping with a fixed curriculum prepared in advance.

The views of the tutors after the course had finished are quite easily stated: if Unesco can continue to stage such training programmes aimed at producing interested young men and women who will be disciples of the marine sciences in their own countries, much of value will be achieved. If, on the other hand, such courses should ever trend towards ambitious university teaching, their value would be much less.
J. N. Carruthers

\title{
NUCLEAR SCIENCE AND THE TRAINING OF YOUNG PEOPLE IN FRANCE
}

$\mathrm{T}$ HE Syndicat National des Instituteurs, the Commissariat à l'Energie Atomique and the Institut Pédagogique National have taken the initiative during the past year to provide school-children in France with courses treating the nuclear sciences in as simple and attractive a form as possible at various scholastic levels.

Thus, since November 1959, thanks to the general secretary of the Syndicat des Instituteurs, M. Forestier, the Ecole Liberatrice has undertaken the publication of leaflets dealing with the nuclear sciences. These leaflets, prepared by Prof. M. Seguy, professor in the College of General Education, supply teachers with pedagogic information which can be presented straight away to their pupils. To further this effort, some weeks ago MM. Seguy and Beaussier, head of the Service d'Orientation Professionnelle of Seine-etOise, took part in three school television programmos designed to familiarize children in the higher classes with the applications of nuclear energy. However, some thought had to be given to reaching older children, in the 15-17 age-group, as well as adults.

To fill a need for popularization which the national Press cannot adequately satisfy, the Institut Péda- gogique National and the Commissariat à l'Energie Atomique have collaborated in organizing a serious audiovisual nuclear education programme. 'Thanks to the initiative and energy of M. Mesnier of the latter, and the teaching capabilities of M. Guillien of the former, a basic course followed by tests has been prepared and put into practice in less than six months. Eight lessons of $25 \mathrm{~min}$. each, making up a course entitled "Initiation into Nuclear Physics", have been organized and filmed at the Institut National des Sciences et Techniques Nucléaires at Saclay, with the collaboration of a young professor, M. Cambou.

In this course, which ranges from the structure of matter to the running of a nuclear reactor, all the multiple resources of audiovisual methods, namely, diagrams, cartoons, outdoor films, laboratory experiments, have boen used to complement the instruction given by the teacher.

These courses were shown on television each Friday during November and December at 6.30 p.m., an hour suitable for viewing either in the teaching establishments, particularly in the case of boarders, or in homes or factories after work. An accompanying 
40-page pamphlet enlarging on the lessons was sent to all interested telovision viewers. This pamphlet contains a series of simple problems printed on detach. able pages, to be sent back when solved to the Institut Pédagogique National.

This project, the first of its kind in Europe, seems to have achieved considerable success.

The corrospondence received by the Institute Pédagogique National has boaten all records. The first transmissions produced more than 2,000 letters from viewers, and more than 12,000 pamphlets have now been sent out.

Certain industrial firms have organized viewing facilities for their technical personnel, with an instructor present. Twelve copies of each film have already been ordered for various schools. The Univorsity of Montpellier intends to use them on the occasion of the Journéos Nucléaires during March 1962. Translations are already being requested from foroign countries.
J. Debiesse:

\section{RUDOLPH VIRCHOW MEDICAL SOCIETY}

T HE ono-hundredth anniversary of the Rudolf Virchow Medical Society of Now York was marked by special celebrations. In his presidential address*, Prof. Joseph Berberich described how the original Society, Deutscher Medizinischer Lcseverein von New York, was foundod in December 1860 by a small group of German physicians, some of whom had left their Fatherland after the Rovolution of 1848. They wanted that freedom of expression for the same reason that led the patron of the Society, Rudolf Virchow, to emigrate at the same time from Berlin to the relatively free and open-minded University of Würzburg in Bavaria.

They lived mostly in the German quarters and met twice a month for the reading of papers and discussion. The rules of the Society were very strict, with Prussian discipline. If someone was absent from a. meoting he was penalized 25 cents. $A$ number of German medical journals were read and exchanged among the members. By 1888 the number of members incroased to 177 , and the name was changed to the German Medical Society in the City of New York The reputation of the Society grew, and many outstanding physicians from Germany and Austria came to lecture to the Society. Men like E. von Leyden, Robert Koch, P. Ehrlich, F. von Exmarch, Friederich von Müller, F. Sauerbruch, H. Strauss, Pasteur, Victor Schmieden, Killian and others read papers more or less as ambassadors of the European, and particularly of German, medicine, whish was then at its highest level.

- Proceedings of the Rudolf Virchoro Medical Society in the City of New York. 19, 1960 . Edited by Hans E. Bejach, Hans Lehfeldt and George Schreiber. Pp. vi +246. (Basle and New York: S. Karger, 1061.) 31 Swiss franes.
A second and influential impulse came after the First World War. The lost war and economic disaster made living difficult for many physicians in Cermany. A great number left Germany for the United States. Those who stayed in New York found rofuge in the Society. At the time it was not difficult for the newcomers to mix with the native physicians, since many American doctors were trained in Germany and Austria and were well versed in the German language.

Medical life after the First World War became more stimulating. With enormous financial backing the United States was soon a leading nation in the field of medicine. The gathering of political clouds in Europe in the beginning of the 'thirties cast a shadow on the Society. Political friction started among members and a number of them resigned. The exodus of a misled group of fanatics did no permanent harm. On June 10, 1939, the namo was changed to the Rudolf Virchow Modical Society in the City of New York.

Almost at the same time (1938-39) came the third and greatest influx of German and Middle-European physicians to the United States. This wave of medical emigrants brought not only their own patients but also a good medical training and considerable exporience. Members of the Society did fundamontal roscarch in nerve electrophysiology, in the development of insulin shock, electro-shock or electroencephalography, the cure of tuberculosis with now ohomicals, treatment of nephrosis, histopathology of mental diseases, introduction of wetting agents into dermatology, the tuberculin patch test, noradrenalin in hyportension, mercury as a diureticum, diagnostic $\mathrm{X}$-ray methods such as arteriography and venography, and myelography.

\section{CENSUS OF SOVIET ZOOLOGISTS}

THE Zoological Institute of the U.S.S.R. Academy of Sciences published, in the form of a small book*, a list of Soviot zoologists, based on replios to a questionnaire sont out in 1958 to all universitics, research institutes and organizations employing pure and applied zoologists. Although the editors complain that many zoologists did not fill in the returns, the list comprises 2,738 (not 2,800 as stated in the preface) entries. It is arranged in alphabetical order of surnames and for each person his full name (both in Russian and in Latin characters), dato of birth, present post, official and privato address, and his speciality aro given.

* Zoologists of the Soviet Dnion. Pp. 290. (Moscow-Leningrad, 1961).
A classification by specialists at the end of the book is of interest, providing some indication of the present trends in Soriety zoology. The largest group (509) is that of parasitologists; this may reflect tho fact that the director of the Zoological Institute, Academician E. N. Pavlovsky, has devoted many years to doveloping this particular branch of zoology. It is closely followed by entomologists, of which thore are 506 ; but, unfortunately, there is no soparate heading for cconomic entomologists, who appear to be a majority, nor for insect ccologists. Othor mainly applied zoologists include hydrobiologists (272); medical zoologists (140); zoologists working on commercial hunting, wildfowling, ctc. (125); agricultural zoologists ( 2 only); bee specialists (13); 